
\title{
LOWER INCISOR INCLINATION IN RELATION TO HEAD POSTURE,
TONGUE AND HYOID POSITIONS
}

\section{ABSTRACT}

Objectives: To investigate the relationship between head posture, hyoid bone, tongue position and lower incisor inclination.

Materials and Methods: The study sample consisted of 98 subjects (35 males, 63 females), who had a mean age of 17.7 years in the permanent dentition and with a skeletal Class I relationship. Lower incisor inclination, craniovertical, craniocervical and craniohorizontal postural variables, tongue and hyoid position and airway measurements were evaluated on lateral cephalograms taken in natural head position. The study sample was divided into two groups according to lower incisor inclination (48 had IMPA $<90$ with a mean degree of 88.09 and 50 had IMPA>90 with a mean degree of 102.84) and a Student-t test was performed to compare and describe head posture, tongue and hyoid bone positions.

Results: The subjects with upright incisors had a more posteriorly positioned hyoid bone relative to the mandibular symphysis compared with the subjects with flared incisors $(\mathrm{p}<0.05)$. Tongue length was greater in the flared incisor group than in the upright incisor group $(\mathrm{p}<0.05)$. In relation to head posture measurements, the upright incisor group had 3-3.5 larger cranio-cervical angles (NSL-OPT, NSL-CVT, NL-OPT, NL-CVT angles, p<0.05) than the flared incisor group. The airway measurements revealed no statistically significant difference between the groups.

Conclusions: The position of the hyoid bone, tongue length and craniocervical head posture showed significant differences between upright and flared lower incisors.

Keywords: Incisor, posture and hyoid bone.

\footnotetext{
${ }^{1}$ Department of Orthodontics, Faculty of Dentistry, Altınbaş University, Istanbul, Turkey

${ }^{2}$ Department of Orthodontics, Faculty of Dentistry, Başkent University Istanbul Hospital, Istanbul, Turkey
}

-0001-7955-3086 D.K. 0000-0001-9123-2744

\section{Received : : 12.04.2019 Accepted : 25.06.2019}

*Seden Akan ${ }^{1}$

Defne Keçik ${ }^{2}$

How to Cite: Akan S, Keçik D. Lower Incisor Inclination in Relation to Head Posture, Tongue and Hyoid Positions. Cumhuriyet Dent J 2019;22:3:310-317. 


\section{INTRODUCTION}

Increasing attention has been directed to the interaction between form and function in the craniofacial region. Craniocervical, equilibrium and normal oral function has a recorded relationship with the position of the lower incisors within the facial framework. ${ }^{1,2}$ The labiolingual inclination of the lower incisors contributes to facial appearance and function. In addition, lower incisor position has an important role in the development of a malocclusion, through the force effects generated by the tongue and lips, habits, occlusal forces, head and cervical posture, and hyoid bone position.

It has been shown that cervical posture is related to craniofacial morphology. ${ }^{3,4,5}$ Solow and Tallgren $^{3}$ stated that extended craniocervical posture is related to increased anterior facial height, reduced sagittal jaw dimensions and a stepped inclination of the mandible. Whereas a flexed head position related to the cervical column is related to reduce facial height, larger sagittal jaw dimensions and a flattened mandibular plane. Rocabado et $a .^{6}{ }^{6}$ indicated that a strong relationship exists between head posture and malocclusion. Solow and Sonnesen ${ }^{5}$ showed that a factor which could affect dental arch crowding was the posture of the head in relation to the cervical column (craniocervical posture). This conclusion was a result of a soft tissue stretching hypothesis associated with an increased dorsallydirected soft tissue pressure which exists in subjects with extended craniocervical posture. Recently, Pachi et al. ${ }^{7}$ found an association between the extended head posture and lower crowding of $2 \mathrm{~mm}$ or more. It was also explained that this relation by the stretching of the soft tissue layer that covers the head and neck during extension. A second possible explanation for this association is possibly that the subjects with nasal airway obstruction presented reduced incisor inclinations and crowding. ${ }^{8,9}$

An important feature craniofacial morphology in relation to cervical posture is hyoid bone position. The supra- and infrahyoid muscles connect the hyoid bone to surrounding structures such as the tongue, the mandible, the base of the skull, the sternum, the scapula, the thyroid cartilage and the pharynx. Because of the complex attachments of the hyoid bone to neighboring anatomical structures, changes in the position may influence hyoid bone position. ${ }^{10}$ It has been also shown that there is a significant relationship between mandibular position and hyoid bone position, particularly related to head posture changes. ${ }^{11,12}$ Based on the assumption that hyoid bone may, therefore, be a dependent structure on many tissues in the craniomandibular system, it is of interest to determine whether lower incisor inclination could be linked to hyoid bone position.

The tongue has the ability to affect the position of teeth and other structures. ${ }^{13}$ Peat $^{14}$ stated that the tongue has an important role in positioning the dentoalveolar structures. Although it is attached principally to the mandible and hyoid bone ${ }^{15}$, the posture, size and the shape of the tongue are the main factors affecting the dentoalveolar form.

Another factor which may affect the lower incisor inclination could be the airway dimensions. A normal airway is accepted as an important factor for the spatial positioning of the craniofacial structures. The relation between airway obstruction and incisor inclination has been described by Linder-Aronson ${ }^{8}$ and Woodside et al. ${ }^{9}$ It has been shown that subjects with nasopharyngeal airway obstruction had greater crowding and reduced incisor inclinations compared with subjects without obstruction. In addition to that, after adenoidectomy, and with the regain of nasal respiration, an increased inclination of the incisors was observed.

The association between lower incisor crowding and head posture ${ }^{7}$, skeletal and symphyseal patterns ${ }^{16}$ has been discussed, but to the best of our knowledge, no investigation has been performed evaluating the inclination of the lower incisors related to head, tongue and hyoid positions, as well as nasopharyngeal airway dimensions. Therefore, the aim of present study was to evaluate the relationship between head posture, hyoid and tongue position, airway dimensions and lower incisor inclination. 


\section{MATERIALS AND METHODS}

The material of this retrospective study consisted of pretreatment lateral cephalograms of randomly selected patients treated in the Department of Orthodontics, Baskent University Istanbul Hospital. An informed consent was obtained from all the subjects. A power analysis showed that 98 subjects were sufficient for the study $(\alpha=0.05 ; \mathrm{f}$ (effect size $)=0.5$; power $(1-\beta$ err prob $=0.80)$. Ninety-eight subjects were selected age 12-41 years ( 35 males, 63 females, with a mean age of 17.7 years) on the basis of the following criteria; complete permanent dentition (except the third molars); had good quality lateral cephalometric radiographs, no craniofacial anomalies, systemic muscle or joint disorders; no previous symptoms of upper airway obstruction; no previous orthodontic treatment; and with an ANB angle in the range of $0-4^{\circ}$.

Table 1. Cephalometric landmarks and lines used to evaluate changes in head posture, hyoid and tongue positions, pharyngeal dimensions, and lower incisor inclination.

\begin{tabular}{|c|c|}
\hline Point-line & Definition \\
\hline $\mathrm{S}$ & Centre of the sella turcica of the sphenoid bone \\
\hline $\mathrm{N}$ & Most anterior point of the frontonasal suture in the midsagittal plane \\
\hline Po & Most superior point of the external auditory meatus \\
\hline Point A & Most posterior point in the concavity between anterior nasal spine and the dental alveolus \\
\hline Point B & Most posterior point on the concavity along the anterior surface of the symphysis \\
\hline Go & The most convex point along the inferior border of the ramus \\
\hline M & The most inferior point of the symphysis \\
\hline Rgn & The most posterior point of symphysis \\
\hline $\mathrm{H}$ & The most superior and anterior points on the body of the hyoid bone \\
\hline TT & Tongue tip \\
\hline $\mathrm{V}$ & Base of epiglottis \\
\hline $\mathrm{U}$ & Tip of soft palate \\
\hline C3 & Antero-inferior limit of the third cervical vertebra \\
\hline Ans & Tip of the anterior nasal spine \\
\hline Pns & Tip of the posterior nasal spine \\
\hline L1 & Axial inclination of the mandibular incisor \\
\hline Cv2tg & Tangent point of OPT line on the odontoid process of the second cevical vertebra \\
\hline Cv2ip & The most inferior-posterior point on the corpus of the second vertebra \\
\hline Cv4ip & The most inferior-posterior point on the corpus of the fourth vertebra \\
\hline Ver line & True vertical line projected on the radiograph \\
\hline Hor line & True horizontal line projected on the radiograph \\
\hline NSL & Line extending between sella and nasion \\
\hline CVT & Posterior tangent to the odontoid process through $\mathrm{Cv} 4 \mathrm{ip}$ \\
\hline OPT & Posterior tangent to the odontoid process through $\mathrm{Cv} 2 \mathrm{ip}$ \\
\hline NL & Line extending between Ans and Pns \\
\hline $\mathrm{MnPl}$ & Line extending between gonion and menton \\
\hline
\end{tabular}

The lateral cephalograms were taken using Sirona Orthopose CD Dental X-ray machine (Siemens, Germany). All lateral radiographs were taken by the same operator with the subjects in the natural head position. The cephalometric landmarks and lines used to assess the changes in lower incisor inclination, tongue, soft palate, hyoid position, and airway dimensions are shown in Table 1 and Figure 1. Nasopharyngeal measurements were performed according to the study by Germeç-Çakan et al. ${ }^{17}$ The intraexaminer measurement error was calculated by remeasuring randomly selected 20 radiographs after 2 weeks, and their mean differences were used to determine Pearson's correlation coefficient. A high correlation value of 0.86-0.93 was found for all angular and linear measurements. 


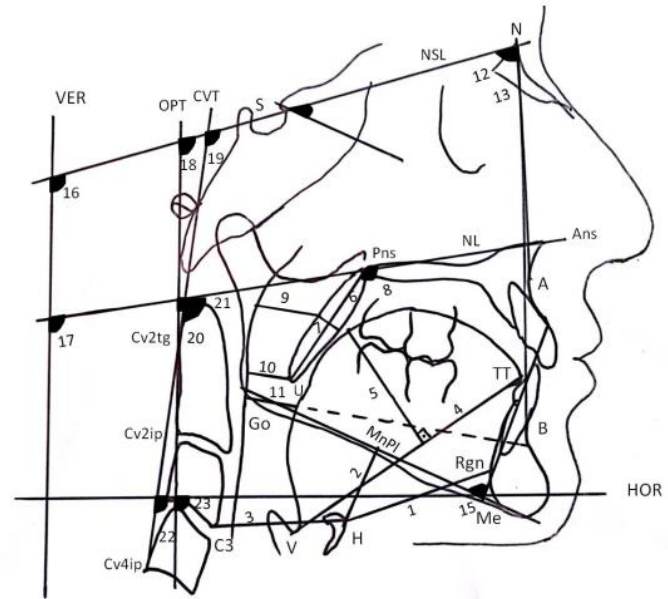

Figure 1. Lateral cephalometric lines and angles. Hyoid and tongue positions, pharyngeal dimensions; $1 \mathrm{Rgn}-\mathrm{H}$, the distance between Rgn and $\mathrm{H} ; 2 \mathrm{H}-\mathrm{MnPl}$, the perpendicular distance from $\mathrm{H}$ to the $\mathrm{MnPl} ; 3 \mathrm{C} 3 \mathrm{H}$, distance between the hyoid bone and $\mathrm{C} 3$; 4 TGL, tongue length (V-TT); $5 \mathrm{TGH}$, tongue height (maximum height of the tongue along a perpendicular line of $\mathrm{V}$-TT line to tongue dorsum); 6 Pns-U, soft palate length, the distance between Pns and U; 7 Mpt, soft palate thickness (maximum thickness of the soft palate measured on a line perpendicular to Pns-U line); 8 Soft palate angle, the angle between soft palate length (Pns-U) and NL; 9 SPAS, superior posterior airway space (width of the airway behind the soft palate along a parallel line to the Go-B line); 10 MAS, middle airway space (width of the airway along a parallel line to the Go-B line through U); 11 IAS, inferior airway space (width of the airway space along the Go-B line); dentofacial measurements; 12 SNA, 13 SNB, 14 ANB, 15 IMPA. head posture measurements; 16 NSL-Ver, downward opening abgle between NSL and true vertical line projected on the radiograph; $17 \mathrm{NL}-\mathrm{Ver}$, downward opening abgle between NSL and true vertical line; 18 NSL-OPT, craniocervical posture, angle formed by NSL line and OPT; 19 NSL-CVT, angle formed by NSL line and CVT, 20 NL-OPT, maxillary base inclination, angle formed by NL line and OPT; 21 NL-CVT, angle formed by NL line and CVT; 22 CVT-Hor, craniohorizontal angle, angle formed by CVT and Hor line; 23 OPT-Hor, angle formed by OPT and Hor line.
The study sample was divided into to two groups. The first group consisted of 48 subjects (34 female, 14 male, mean age of 17.36) with lower incisor inclination angle (IMPA) less than $90^{\circ}$, and identified as flattened incisors. The second group consisted of 50 subjects ( 29 female, 21 male, mean age of 18.02) with an IMPA angle larger than $90^{\circ}$, and identified as flared incisors. Data analysis was performed using the SPSS software package program (SPSS for Windows, version 16.0, SPSS Inc, Chicago, Ill). Student-t test was performed to compare the inclination of the lower incisors related to head posture, and tongue and hyoid bone positions and airway dimensions. $\mathrm{P} \leq 0.05$ values were accepted as significant.

\section{RESULTS}

The 48 subjects of the flattened incisor group showed a mean IMPA of $88.09^{\circ}$, while 50 subjects with flared incisors had a mean IMPA of $102.84^{\circ}(\mathrm{p}<0.001)$. Means and standard deviations of the hyoid bone and tongue positions, pharyngeal dimensions and head posture measurements are presented in Table 2 .

Table 2. Mean, standard deviation and statistical difference of the variables between flared and flattened lower incisor groups according to Student $t$ test.

\begin{tabular}{|c|c|c|c|c|c|c|c|c|c|}
\hline \multirow[b]{2}{*}{$\begin{array}{l}\text { Hyoid and tongue positions, } \\
\text { pharyngeal dimensions }\end{array}$} & \multicolumn{4}{|c|}{$\begin{array}{c}\text { Flattened Lower incisor group } \\
\left(\text { IMPA } \leq 90^{\circ}, \mathrm{n}: 48\right)\end{array}$} & \multicolumn{5}{|c|}{$\begin{array}{l}\text { Flared Lower incisor group } \\
\left(\text { IMPA }>90^{\circ}, \mathrm{n}: 50\right)\end{array}$} \\
\hline & Mean & SD & Min & $\operatorname{Max}$ & Mean & SD & Min & Max & $\mathbf{P}$ \\
\hline Rgn-H & 24.52 & 3.32 & 17 & 32 & 23.08 & 3.71 & 15 & 35 & $0.046^{*}$ \\
\hline $\mathrm{H}-\mathrm{MnPl}$ & 10.39 & 3.72 & 3 & 21 & 9.44 & 3.59 & 1 & 17 & 0.199 \\
\hline $\mathrm{C} 3 \mathrm{H}$ & 21.50 & 2.82 & 11 & 28 & 21.60 & 2.22 & 17 & 28 & 0.756 \\
\hline TGL & 42.08 & 4.44 & 26 & 50 & 43.79 & 3.91 & 32 & 52 & $0.046^{*}$ \\
\hline $\mathrm{TGH}$ & 18.95 & 2.62 & 14 & 25 & 18.78 & 2.75 & 15 & 27 & 0.744 \\
\hline Pns-U & 20.35 & 2.66 & 12 & 25 & 21.38 & 2.49 & 16 & 28 & 0.052 \\
\hline MPT & 4.79 & 1.05 & 3 & 7 & 4.99 & 1.17 & 3 & 7 & 0.379 \\
\hline Soft palate angle & 129.35 & 6.75 & 120 & 145 & 131.62 & 6.11 & 120 & 145 & 0.085 \\
\hline SPAS & 7.83 & 1.87 & 5 & 13 & 7.82 & 1.81 & 4 & 12 & 0.972 \\
\hline MAS & 5.87 & 2.00 & 2 & 11 & 5.44 & 1.76 & 2 & 11 & 0.257 \\
\hline IAS & 6.95 & 1.86 & 3 & 10 & 6.38 & 2.20 & 3 & 12 & 0.165 \\
\hline \multicolumn{10}{|l|}{ Head Posture } \\
\hline NSL-Ver & 99.18 & 5.27 & 87 & 111 & 98.88 & 5.71 & 85 & 113 & 0.785 \\
\hline NL-Ver & 90.19 & 5.52 & 74 & 101 & 90.75 & 5.49 & 75 & 102 & 0.614 \\
\hline NSL-OPT & 104.80 & 6.91 & 90 & 128 & 101.84 & 7.25 & 82 & 115 & $0.041^{*}$ \\
\hline NSL-CVT & 109.42 & 7.59 & 94 & 131 & 105.85 & 7.49 & 90 & 119 & $0.021 *$ \\
\hline NL-OPT & 96.41 & 8.07 & 81 & 119 & 93.11 & 6.36 & 77 & 104 & $0.026^{*}$ \\
\hline NL-CVT & 102.33 & 7.64 & 85 & 126 & 99.19 & 7.52 & 84 & 111 & $0.043 *$ \\
\hline CVT-Hor & 79.24 & 7.92 & 58 & 100 & 81.89 & 8.60 & 62 & 102 & 0.116 \\
\hline OPT-Hor & 83.89 & 8.41 & 59 & 105 & 85.94 & 8.87 & 67 & 104 & 0.243 \\
\hline
\end{tabular}


Table 2 also shows the differences of various parameters between the two groups. According to hyoid bone and tongue position measurements, the subjects with flattened incisors had a mean of $1.44 \mathrm{~mm}$ more posteriorly positioned hyoid bone relative to the mandibular symphysis than the subjects with flared incisors $(\mathrm{p}<0.05)$. Tongue length was found to be $1.71 \mathrm{~mm}$ more in the flared incisor group than flattened group $(\mathrm{p}<0.05)$. Concerning head posture measurements, the flattened incisor group had 3-3.5 larger craniocervical angles (NSL-OPT, NSL-CVT, NL-OPT, NL-CVT angles, $\mathrm{p}<0.05)$ than the flared incisor group. For the airway measurements, no statistically significant differences were found between the groups.

\section{DISCUSSION}

The positions of lower incisor teeth have been considered as a major factor in the development of a malocclusion, facial pattern and orthodontic treatment planning. According to Proffit's equilibrium theory, ${ }^{18}$ the dentition is kept in a balanced position by its environment (peri-oral muscles, tongue, periodontal ligaments, etc.). In this theory, altering the oral environment will cause a change in the occlusion and therefore to create a stable occlusion, teeth should be placed in a position balanced by the surrounding forces. Proffit ${ }^{19}$ revisited the theory and stated that, while the major primary factors in the dental equilibrium could be the pressures of the tongue and lips, periodontal membrane and eruption forces, the forces from the occlusion and respiratory function also influence head, jaw and tongue postures and thereby altered the "equilibrium".

For the lower incisors, equilibrium is created not only by lip and tongue pressures, but also by the craniocervical mandibular system consisting of the temporomandibular joint, cervical column and by the "hanger system" of the hyoid bone. Other basic parts of this system are the dental occlusion, the swallowing mechanism and, the muscles and ligaments that joined each. From these data the authors evaluated the relationship between the inclination of the lower incisors and the surrounding structures creating craniocervical system equilibrium.

According to the results of the present study, the position of the hyoid bone was significantly closer to the mandibular symphysis, and tongue length was increased as well as craniocervical head posture was more flexed (measured with NSL-CVT, NSL-OPT, NL-CVT, NL-OPT) in the flared incisors group than flattened lower incisors group $(\mathrm{p}<0.05)$.

The hyoid bone is an important part of the craniofacial complex and its position relates mandibular position adapting to anteroposterior changes in head position by means of the supraand infrahyoid muscles. ${ }^{11,20}$ Adamidis and Spyropoulos $^{21}$ also showed more anteriorly position of the hyoid bone in the Class III group correlated with Class I subjects. Amayeri et al. ${ }^{22}$ argued that the hyoid bone moved backward as the mandible moved forward and; in the vertical plane, the hyoid bone position was lower position in the Class III malocclusion cases than in Class I and Class II malocclusions. Jena and Duggal ${ }^{23}$ showed the hyoid bone was placed anteriorly in subjects with a short face. Ferraz et al. ${ }^{24}$ mentioned no statistical significant differences in the mandible and hyoid bone position related to the respiratory pattern. According to the results of the present study, subjects with flattened lower incisors showed a more posteriorly positioned hyoid bone to the mandibular symphysis than subjects with flared lower incisors. Previously, it was argued ${ }^{25}$ that head hyperextension was correlated with a greater distance from the hyoid bone to the mandible and to menton.

The tongue plays a role in dental and skeletal malocclusions, thus the size and position of the tongue must also be taken into consideration when planning orthodontic treatment. A short tongue length has been correlated with upright central incisors, a small overjet, a low ANB angle, impacted maxillary and mandibular teeth, and a steep occlusal plane. ${ }^{26}$ Bandy and Hunter ${ }^{27}$ stated that the length of the tongue has little influence on the angle between the axial inclination of the lower incisor teeth to the mandibular plane. Consistent with these studies, the results of the 
present study showed an increased tongue length in the flared lower incisor group.

According to the results of the present study, the flattened lower incisor group showed a mean of $3^{\circ}$ to $4^{\circ}$ larger cranio-cervical angles (NSL/CVT, NSL/OPT, NL/CVT, NL/OPT) than subjects with flared incisors $(\mathrm{p}<0.05)$. Extended head posture caused uprighting of the lower incisors.

Previous studies ${ }^{3,5}$ have found that natural head posture is related to respiratory function. Linder-Aronson $^{8}$ evaluated the dental measurements of children with mouth breathing, enlarged adenoids and obstructed upper airway, and found that the subjects showed retroclined upper and lower incisors. One year after the adenoidectomy, normalization of dental inclination was observed by the authors. Although the study groups were comprised by the subjects with no previous symptoms of the upper airway obstruction, and results showed the pharyngeal airway dimensions have not any significant differences between groups. Lower incisor inclination was still affected by craniocervical head posture. Similar to the results of the present study, an association between extended the head posture and lower arch dental crowding was shown. ${ }^{7}$ It was proposed that another cause of this result may be a "soft tissue stretching mechanism" proposed by Solow and Kreiborg. ${ }^{28}$ According to this theory, an extension of the craniocervical posture causes passive stretching of the soft tissue layer (skin, fascia and muscles) covering the head and neck. A dorsally directed force is created by the stretching of this soft tissue layer which affects dentofacial growth in the long term. According to the equilibrium theory, lower incisor inclinations may be retroclined by this backward guiding force, if the tongue muscle activity is not balanced.

However, if the "soft tissue stretching mechanism" is accepted, the magnitude of these forces should be discussed. Hellsing and L'Estrange $^{29}$ found a significant difference in upper and lower lip pressures between nose breathing and mouth breathing subjects. It was shown that when the head extends $5^{\circ}$ during mouth breathing, a significant increase in upper and lower lip pressures occurred. Archer and
Vig $^{30}$ studied the lip and tongue pressures in subjects with Class I and Class II dental and skeletal morphologies in the natural head position, head extension and head flexion positions. It was stated that the flexion of the head posture caused a significant decrease in the lingual pressure. In agreement with these researchers, the results of the present study indicate that the influence of head posture should be taken into account when evaluating the facial morphology and planning orthodontic treatment.

In the present study, subjects were a wide range of age of 12-41 years. Thus, there is an inherent limitation of the study as the possible effect of growing on head posture, hyoid bone and tongue position, nasopharyngeal airway dimensions and lower incisor inclination. Araújo et $a l .{ }^{31}$ studied the nasopharyngeal patency change on the respiratory function by means of rhinomanometry in individuals in different age groups. They found that children and adults had similar values in the nasopharyngeal space. Thus, the authors concluded the nasopharynx does not change with age. Abramson et al. ${ }^{32}$ showed a proportional increase of the nasopharyngeal space to 20 years, and after a stabile period, a reduce of in size until 50 along the craniofacial growth by evaluating $1300 \mathrm{CT}$ scans of healthy individuals aged 6 to 60 years. Considering the change in hyoid bone position, Matsuda et al. ${ }^{33}$ stated hyoid bone shifted to a posterior, rotated, and lower position with increasing age in their cross sectional study using lateral cephalometric radiographs in 22 to 84 years old patient. Agelower incisor position relationship was evaluated by Linjawi's study ${ }^{34}$ and the author argued that age- and gender-related lower incisor changes significant only in subjects with brachifacial pattern. Present study was focused head posture, hyoid bone, tongue position and lower incisor inclination instead of vertical growth pattern.

\section{CONCLUSIONS}

The results of the present study may be summarized as follows:

The hyoid bone is positioned significantly closer to the mandibular symphysis in subjects with flared lower incisors. 
Craniocervical head posture showed more flexion and tongue length increased in the subjects with flared incisors than flattened lower incisors.

\section{ACKNOWLEDGEMENTS \\ Funding}

The authors declare that they have not received funding.

\section{CONFLICT OF INTEREST STATEMENT}

The authors declare that they have no conflict of interests.

\section{Alt Keser İnklünasyonunun Baş Postürü, Hyoid ve Dil Pozisyonu ile İlişkisi}

\section{$\ddot{O} Z$}

Amaç: Bu çalışmanın amacı alt keser inklinasyonunun; baş postürü, hyoid kemik ve dil pozisyonu ile olan ilişkinin araştırılmasıdır. Gereçler ve Yöntem: Çalışma grubu ortalama yaşları 17,7 yaş olan daimi dentisyonda, iskeletsel Angle sinıf I ilişkiye sahip 98 bireyden (35 erkek, 63 kız) oluşmaktadir. Alt keser inklinasyonu (IMPA), kraniovertikal, kranioservikal ve kraniohorizontal postüral değişkenler, hyoid ve dil pozisyonlar doğal baş pozisyonunda alınan lateral sefalogramlar üzerinde değerlendirilmiştir. Baş postürüyle ilişkili olarak alt keser inklinasyonlarını karşılaştırmak için çalışma grubu ikiye ayrılmış (48 kişide ortalama $88,09^{\circ}$ olmak üzere IMPA $<90^{\circ}$ ve 50 kişide ortalama $102,84^{\circ}$ olmak üzere IMPA $>90^{\circ}$ ) ve Student-t testi uygulanmıştır. Bulgular: Dikleşmiş alt keserlere sahip grup, labiale eğimli gruba göre daha arka pozisyonda konumlanmış hyoid kemiğine sahiptir $(p<0,05)$. Bununla birlikte yine dikleşmiş keserlere sahip bireylerin ortalama $3-4^{\circ}$ daha geniş kranioservikal açlara (NSL/OPT, NSL/CVT, NL/OPT, NL/CVT) sahip olduğu bulunmuştur ( $<<0,05)$. Havayolu ölçümleri iki grup arasında anlamlı farklılık göstermemiştir. Sonuç: Çalışmamızın sonuçlarına göre, hyoid kemiği pozisyonu, dil uzunluğu ve kranioservikal baş pozisyonu; dikleşmiş ve labiale eğimli alt keser gruplarında anlamlı farklılıklar göstermiştir. Anahtar Kelimeler: Kesici diş, postür ve hyoid kemik.

\section{REFERENCES}

1. Knosel M, Jung K. On the relevance of "ideal" occlusion concepts for incisor inclination target definition. Am J Orthod Dentofacial Orthop 2011;140:652-659.
2. Hernandez-Sayago E, Espinar-Escalona E, BarreraMora JM, Ruiz-Navarro MB, Llamas-Carreras JM, Solano-Reina E. Lower incisor position in different malocclusions and facial patterns. Med Oral Patol Oral Cir Bucal 2013;18:43-50.

3. Solow B, Tallgren A. Head position and craniofacial morphology. Mondo Ortod 1978;19:75-99.

4. Marcotte MR. Head posture and dentofacial proportions. Angle Orthod 1981;51:208-213.

5. Solow B, Sonnesen L. Head posture and malocclusions. Eur J Orthod 1998;20:685-693.

6. Rocabado M, Johnston BE Jr, Blakney MG. Physical therapy and dentistry: an overview. J Craniomandibular Pract 1983;1:46-49.

7. Pachi F, Turla R, Checchi AP. Head posture and lower arch dental crowding. Angle Orthod 2009;79:873-879.

8. Linder-Aronson S. Adenoids. Their effect on mode of breathing and nasal airflow and their relationship to characteristics of the facial skeleton and the denition. A biometric, rhino-manometric and cephalometroradiographic study on children with and without adenoids. Acta Otolaryngol Suppl 1970;265:1-132.

9. Woodside DG, Linder-Aronson S, Stubbs DO. Relationship between mandibular incisor crowding and nasal mucosal swelling. Suom Hammaslaak Toim 1991;87:127-138.

10. Marşan G, Oztaş E, Cura N, Kuvat SV, Emekli U. Changes in head posture and hyoid bone position in Turkish Class III patients after mandibular setback surgery. J Craniomaxillofac Surg 2010;38:113-121.

11. Valenzuela Z, Miralles R, Ravera M. Does head posture have a significant effect on the hyoid bone position and sternocleidomastoid electromyographic activity in young adults? J Craniomandibular Pract 2005;23: 204-211.

12. Adamidis IP, Spyropoulos MN. Hyoid bone position and orientation in Class I and Class III malocclusions. Am J Orthod Dentofacial Orthop 1992;101:308-312.

13. Verma SK, Tandon P, Agrawal DK, Prabhat KC. A cephalometric evaluation of tongue from the rest position to centric occlusion in the subjects with class II division 1 malocclusion and class I normal occlusion. J Orthod Sci 2012;1:34-39.

14. Peat JH. A cephalometric study of tongue position. Am J Orthod 1968;54:339-351. 
15. Milne IM, Cleall JF. Cinefluorographic study of functional adaptation of the oropharyngeal structures. Angle Orthod 1970;40:267-283.

16. Gutermann C, Peltomaki T, Markic G, Hänggi M, Schätzle M, Signorelli L, Patcas R. The inclination of mandibular incisors revisited. Angle Orthod 2014;84:109-119.

17. Germec-Cakan D, Taner T, Akan S. Uvuloglossopharyngeal dimensions in non-extraction, extraction with minimum anchorage, and extraction with maximum anchorage. Eur J Orthod 2011;33:515520 .

18. Weinstein S, Haack DC, Morris LY, Snyder BB, Attaway HE. On an Equilibrium Theory of Tooth Position. Angle Orthod 1963;33:1-26.

19. Proffit WR. Equilibrium theory revisited: factors influencing position of the teeth. Angle Orthod 1978;48:175-186.

20. Opdebeeck H, Bell WH, Eisenfeld J, Mishelevich D. Comparative study between the SFS and LFS rotation as a possible morphogenic mechanism. Am J Orthod 1978;74:509-521.

21. Adamidis IP, Spyropoulos MN. The effects of lymphadenoid hypertrophy on the position of the tongue, the mandible and the hyoid bone. Eur J Orthod 1983;5:287-294.

22. Amayeri M, Saleh F, Saleh M. The position of hyoid bone in different facial patterns: A lateral cephalometric study. Eur Sci J 2014;10:19-34.

23. Jena AK, Duggal R. Hyoid bone position in subjects with different vertical jaw dysplasias. Angle Orthod 2011;81:81-85.

24. 24.Ferraz MJ, Nouer DF, Teixeira JR, Bérzin F. Cephalometric assessment of the hyoid bone position in oral breathing children. Braz J Otorhinolaryngol 2007;73:45-50.
25. Weber P, Corrêa ECR, Bolzan PG, Ferreira FS, Soares JC, da Silva AMT. Relationship between craniocervical posture, mandible and hyoid bone and influence on alimentary functions. Braz J Oral Sci 2012;11:141-147.

26. Lowe AA, Takada K, Yamagata Y, Sakuda M. Dentoskeletal and tongue soft-tissue correlates: a cephalometric analysis of rest position. Am $\mathbf{J}$ Orthod 1985;88:333-341.

27. Bandy HE, Hunter WS. Tongue volume and the mandibular dentition. Am J Orthod 1969;56:134-142.

28. Solow B, Kreiborg S. Soft-tissue stretching: a possible control factor in craniofacial morphogenesis. Scand J Dent Res 1977;85:505-507.

29. Hellsing E, L'Estrange P. Changes in lip pressure following extension and flexion of the head and at changed mode of breathing. Am J Orthod Dentofacial Orthop 1987;91:286-294.

30. Archer SY, Vig PS. Effects of head position on intraoral pressures in Class I and Class II adults. Am J Orthod 1985;87:311-318.

31. Araújo LL, Silva ASC, Araújo BMAM, Yamashita RP, Trindade IEK, Fukushiro AP. Nasopharyngeal dimensions in normal individuals: normative data. CoDAS 2016;28:403-408.

32. Abramson Z, Susarla S, Troulis M, Kaban L. Agerelated changes of the upper airway assessed by 3dimensional computed tomography. J Craniofac Surg 2009;20:657-663.

33. Matsuda Y, Ito E, Kimura Y, Araki K. Hyoid bone position related to gender and aging using lateral cephalometric radiographs. Orthodontic Waves 2018;77:226-231.

34. Linjawi AI. Age- and gender-related incisor changes in different vertical craniofacial relationships. J Orthod Sci 2016;5: 132-137. 